\title{
Tibia pilon kırıklarının tedavisinde kullanılan cerrahi yaklaşımlar
}

\author{
Surgical approaches for tibia pilon fractures
}

\author{
Bülent Dağlar
}

Özel Ankara Güven Hastanesi, Ankara

Tibia pilon kırıkları, ortopedi ve travmatolojinin yeni yaklaşım, teknik ve implant arayışlarının devam ettiği sıcak konularından biridir. Sonuçları etkileyen faktörler içinde tedavi eden hekimin değiştirebilecekleri; eklem yüzünün anatomik yeniden oluşturulması, dizilim ve yönelimin elde edilerek erken harekete izin verebilecek sağlamlıkta bir tespitin yapılabilmesidir. Tüm bunların sağlanabilmesi, öncelikle kırık ve yaralanmanın çok iyi anlaşılmasına ve iyi bir planlama ile yumuşak dokulara en az zarar verecek girişimlerin seçilmesine bağlıdır. İleri yumuşak doku hasarı ile birlikte olan pilon kırıklarında, iki aşamalı cerrahinin iyi sonuçlar verdiği söylenebilir. Tespit için kullanılacak implant tipi daha az önemli olmakla birlikte, cerrahi sırasında farklı boyut ve tipte implantların elde bulundurulması sürprizleri azaltır. Bu tedavisi zor yaralanmaların tedavisinde tecrübe edinmek ve iyi sonuçlar alabilmek için, kadavra üzerinde anatomi çalışmaları yapılması yararlı olacaktır.

Anahtar sözcülkler: tibia pilon; cerrahi tedavi; cerrahi yaklaşım
Tibia pilon fractures are one of the hot topics of orthopaedics and traumatology with current need for the new approach, technique, and the implant. Factors that surgeon can change are: anatomical reconstruction of joint surface, obtaining anatomical joint alignment and orientation, and obtaining stable fixation allowing early pain free active motion. Above mentioned goals can primarily be achieved with perfect fracture characterization, thorough operative planning and procedures that do not further increase the current soft tissue injury. Current orthopedic literature supports staged surgery for pilon fractures with advanced soft tissue injury. Although the choice of implant is not that much important, having different sizes and types of implants in the operating theater may decrease unwanted surprises. Anatomical dissection on cadavers would be very helpful to improve knowledge and skills necessary for good outcomes in these complex injuries.

Key words: tibia pilon; surgical treatment; surgical approach
E rişkin tibia distal metafizinin de etkilendiği eklem içi kırıklar, tibia pilon veya plafond kırıkları olarak isimlendirilir. Tedavi sonucunu etkileyen en önemli etmenler; yaralanmanın enerjisi, eklemdeki parçalanma miktarı, metafizdeki parçalanma ve yapısal kayıp ile belki de bunlar içinde en önemlisi olarak yaralanma bölgesini çevreleyen yumuşak dokudaki hasar miktarıdır. ${ }^{[1]}$ İyi klinik sonuçlar için; eklem yüzünün yeniden anatomik olarak oluşturulması, eklem bloğu dizilim ve yöneliminin komşu eklemlerle ilişkisinin normal anatomiye en yakın şekilde düzenlenmesi ve mümkün olan en erken dönemde eklem hareketlerine izin verecek sağlamlıkta tespit yapılması temel hedeflerdir. ${ }^{[1]}$

Birçoğu yüksek enerji ile oluşan pilon kırıklarında, eklem yüzünün anatomik olarak yeniden oluşturulması için sıklıkla cerrahi tedaviler gerekir. Yumuşak dokuların yüksek yaralanma enerjisi nedeniyle sıklıkla ciddi hasarlandığı bu kırıklarda, yapılacak açık cerrahi girişimlerinin en az seviyede ek doku hasarı oluşturması iyi klinik sonuçlar için bir gerekliliktir. Bu durumda, açık girişim yolu çok iyi bir planlama ile seçilmeli ve hassas bir teknikle uygulanmalıdır. Kemiği örten yumuşak doku, özellikle mediyalde çok incedir. Kesilerin tam kat flepler oluşturmaması halinde, perforan damarlardan gelen kanlanma bozulur ve iyileşme sorunları ortaya çıkar. Birden fazla kesi ile cerrahi planlandığında, kesiler arasındaki mesafenin mümkün olduğunca uzun tutularak fleplerin beslenmesinin risk edilmemesi, kırık iyileşmesi açısından da önemlidir. Yumuşak doku açılımı sırasında venlerin de mümkün olduğunca korunması, ameliyat sonrası şişliği azaltır ve muhtemel kalıcı şişliklerin önlenmesine yardımcı olur.

- Illetişim adresi: Dr. Bülent Dağlar, Özel Ankara Güven Hastanesi, Şimşek Sok. No:29, Kavaklıdere, Ankara

Tel: 0312 - 4572490 e-posta: bulentdaglar@gmail.com

- Geliș tarihi: 3 Mayıs 2016 Kabul tarihi: 3 Mayıs 2016 


\section{FiBULA KIRIĞININ ÖNEMI VE TEDAVISi}

Pilon kırıklarının \%90'ında fibula kırı̆ı da bulunur. Fibula kırığının eşlik etmediği iki tip pilon kırığından bahsedilebilir. Birinci grup pilon kırığında, düşük enerjili rotasyonel yaralanma söz konusudur. Diğer grup, yani fibula kırığının eşlik etmediği saf aksiyel yüklenme sonucu oluşan pilon kırığında, sonuçlar eklem kıkırdağındaki aşırı parçalanma ve ezilme nedeniyle çok daha kötüdür. Rüedi ve Allgöwer, pilon kırıklarının son on yıla kadar sık kullanılan sınıflamasını yapmış, aynı zamanda bu zor kırıklardaki tedavi stratejisini de ortaya koymuşlardır. Bu yazarlara göre, pilon kırıklarında doğru redüksiyonun anahtarı fibulanın anatomik bütünlügünün tekrar oluşturulmasıdır. Fibulanın boy, dönüklük ve açılanmasının anatomik redüksiyonu, bilinen eklem yüzü ilişkileri kullanılarak yapılacak tibia distal eklem yüzü anatomik redüksiyon girişimlerinin birinci basamağı olarak kabul edilmiştir. Günümüzde de halen genel olarak bu görüş geçerlidir. Anatomik redüksiyonun elde edilebileceği segmenter kayıpsız, fazla parçalanması olmayan pilon kırıkları cerrahi olarak tedavi edilirken, ilk basmak olarak fibula redükte ve tespit edilir. Ancak, anatomik redüksiyonun mümkün olamayacağı çok parçalanmalı fibula kırıklarının, pilon kırı̆gı redüksiyonu ve tespiti sonrası tespiti, ortopedi ve travmatoloji literatüründe geçerli bir görüş olarak yerini almaktadır. ${ }^{[1]}$ Çok parçalı fibula kırıkları, sıklıkla, benzer şekilde fazla parçalanmalı ve metafiz bölgesinde fazla kemik ezilmesi olan pilon kırıklarına eşlik eder. Bu durumda, fibulanın boyunun parçalanma nedeniyle uygun restore edilmemesi halinde, pilon ve metafiz redüksiyonundaki hata ihtimali de artar. $\mathrm{Bu}$ durumlarda, önce pilon ve metafiz dizilim-yöneliminin elde edilerek, sonrasında bilinen anatomik ilişkilere göre fibulanın düzeltilmesi, daha uygun bir ayak bilek anatomik ilişkisi ve işlevi sağlar.

Fibula kırığındaki yer değiştirme ve açılanma, cerrahi planlama sırasında da yardımcı bilgiler verir. Genel olarak, fibula kırığındaki lateral yer değiştirme ve açılanma, tibia distalinde lateral kolonda daha fazla parçalanma olduğunun ve bu bölgenin desteklenmesi gereğinin işareti sayılır. Mediyal yer değiştirme ve açılanma ise mediyal kolonda daha fazla parçalanma olduğunun ve bu bölgenin desteklenmesi gerektiğinin işareti olarak değerlendirilir.

Fibula ile ilgili bir diğer bahse değer konu, tespit zamanlamasıdır. Pilon kırıklarının cerrahi tedavisinde erken, yumuşak doku iyileşmesine izin veren geçici eksternal tespit ve genellikle 10-20 gün sonrasında kalıcı asıl tespit stratejisi, son 10 yılın en çok taraftar bulan seçeneğidir. Bekleme süresinde dizilimin ve uzunluğun daha iyi korunmasına yardımcı olacağı için, bir grup yazar, fibula kırığının redüksiyon ve tespitini önerir.
Diğer bir görüş ise, fibula girişimi için kullanılacak lateral kesinin muhtemel anterolateral ayak bilek kesisi ile yakınlığının cilt dolaşımını riske edebileceğidir. Bu nedenle, eğer ilk girişim öncesi fibula redüksiyon ve tespiti düşünülüyorsa pilon kırı̆ğ için kesin tedavi planının yapılmış olması, anterolateral kesi kullanılması ön görülüyor ise fibula girişimi için kesinin daha posterior veya posterolateral şekilde yapılması uygun olacaktır. Direkt anterior veya anteromediyal girişim kesileri ise, genellikle fibula için kullanılan lateral kesi ile birlikte oluşan flebin dolaşımını daha az bozduğu için güvenli biçimde kullanılabilir.

\section{ERKEN EKSTERNAL FIKSATÖR UYGULAMASI, KALICI REDÜKSIYON VE TESPIT ZAMANLAMASI}

Yüksek enerjili pilon kırıklarının tedavisinde yumuşak dokularda kalıcı tedaviye izin verecek iyileşmenin sağlanması için, sıklıkla eksternal fiksatörler kullanılır. Geçici olarak kullanıldığında, ayak bilek eklemini geçen/köprüleyen tipte fiksatörlerin kullanımı daha sıktır. Her türlü eksternal fiksatör, yumuşak doku iyileşmesi sırasında ara tedavi için kullanılabilir. Tüm eksternal fiksatör uygulamalarında dikkat edilmesi gereken konulardan biri, talusun yarı çıkık veya çıkık halinin düzeltilmesidir. Hasta supin pozisyondayken, bacağın altına onu bütünüyle destekleyecek biçimde yerleştirilecek yükseklik, dizi yaklaşık $20^{\circ}$ fleksiyona getirerek, önemli bir deforme edici güç olan gastroknemiusu gevşetir. Ayağın bu destekten sarkması sağlanarak, talusun öne yer değiştirmesi kontrol edilebilir. [2] Tek taraflı şanz vidalarının uygulandığı sistemlerde, ilk olarak tibiada mümkün olan en proksimal bölümde anteromediyal şanz vidası yerleştirilir. İkinci şanz vidası sıklıkla kalkaneus cismine mediyalden yerleştirilerek, iki şanz yardımlı traksiyon ile kırık bölgesinde mümkün olan redüksiyon elde edilmeye çalışılır. Üçüncü şanz vidası, tibiada proksimal şanzın distaline, kalıcı tespitte kullanılma ihtimali olan plağın proksimalinde kalacak biçimde yerleştirilir. Dördüncü şanz vidası, yine kalkaneus veya talus cismine yerleştirilerek çerçeve sağlamlaştırılır. ${ }^{[3]} \mathrm{Bu}$ uygulama, şanz vidaları ve boruların ayrı ve serbest olarak uygulanabildiği sistemlerle daha kolay gerçekleştirilir. Tek taraf ve tek planlı fiksatörlere göre iki taraf veya iki planlı fiksatörler daha sağlam tespit sağlar. Bu nedenle, daha fazla sağlamIık istendiğinde delta çerçeve sistemi kullanılabilir. Bu çerçeve için, kalkaneusa yerleştirilen şanz vidası uzun seçilerek lateralden çıkarılır ve proksimaldeki şanz vidaları bu şanz vidasının hem mediyaline hem de lateraline tutturulur. Geçici tespit için sirküler fiksatörler de kullanılabilir. Ancak bu tip çerçevenin kurulması, zaman alacağı ve yumuşak doku tedavisinde muhtemel ek girişimleri zorlaştırabileceği için tercih edilmez. Tek 
parçalı fiksatörlerde, şanz vidaları sistemin tutaçlarının izin verdiği şekilde yerleştirilir. Yumuşak doku iyileşmesinin iki haftadan uzun süreceğinin ön görülmesi halinde, ayağın da fiksatör ile tespiti, muhtemel ekin pozisyonundaki sertlikleri engellemek için önemlidir. Uzun süreli tespitlerde, ekin pozisyonu sadece ayağın arka bölümünden değil, sıklıkla talonaviküler eklemin etkilendiği orta bölümünden de oluşabileceği için, ayak orta kısmının fiksatör sistemine eklenmesi yararı olabilir. ${ }^{[2]}$ Ancak, ayak parçasının kullanılması biyomekanik olarak her zaman gerekli değildir. ${ }^{[4]}$ Geçici eksternal fiksatör uygulamalarında dikkat edilmesi gereken önemli noktalardan biri de, şanz vidası veya tel giriş yerlerinin planlanan açık cerrahi kesilerinin içinde kalmamasına özen gösterilmesidir. Eksternal fiksatörün yedi günden fazla kaldığı durumlarda, çivi veya tel diplerinde enfeksiyon ihtimalini arttıran ciddi kolonizasyon oluşmaktadır. Doksan yedi pilon kırı̆ıının da içinde olduğu geriye dönük bir çalışmada, kalıcı tespit için plak kullanılacaksa, önceden uygulanan eksternal fiksatör çivilerinin kalıcı tespit için kullanılan tedavi alanında kalmış olmasının enfeksiyon oranını \%24'lere kadar arttırdığı bulunmuştur. ${ }^{[5]}$

Kalıcı düzeltme ve tespitin zamanlaması, yumuşak dokuların iyileşmeyi kötü etkilemeyecek şekilde işleme izin vermesine bağlıdır. Yaralanmanın enerjisi, kırığı çevreleyen yumuşak dokularda kaçınılmaz bir hasar oluşturur. Yapılacak kalıcı tedavide, bu hasarlı dokunun iyileşme potansiyelini aşacak işlemlerden kaçınılmalıdır. Kapalı yumuşak doku yaralanması sınıflandırımalı, hasarın görünenden fazla olduğu akılda bulundurulmalıdır. Kapalı yumuşak doku yaralanmalarının sınıflandırılmasında, halen en sık Tscherne'nin tanımladığı sistem kullanılmaktadır. ${ }^{[6]}$ Tscherne 0 ve 1 pilon kırıkları, genellikle düşük enerjili ve yumuşak doku hasarının az olduğu yaralanmalardır ve gereken hazırlıklar yapıldıktan sonra erken dönemde tedavi edilebilir. Tscherne 2'de, sıklıkla yaralanmayı izleyen ilk 12 saatte kırık bölgesinde büllerin oluştuğu gözlenir. Büllerin şeffaf, transüda ile dolu olması kısmi dermal hasar işaretiyken, kanlı büller tam kat ve daha ciddi hasarın belirtisidir. Büllerin kendi haline bırakılarak iyileşmesi beklenebilir. Şeffaf büller genellikle 7-10 günde, kanlı büller ise 14-20 gün içinde cerrahiye izin verecek şekilde iyileşir. Ancak her halükarda, özellikle kanlı, iyileşmiş bül yakınından kesi yapılmasından kaçınılmalı, görünmeyen hasar bölgesinin bülün kendisinden daha geniş bir alanda olduğu akılda bulundurulmalıdır. îleriye dönük randomize bir çalışmada, büllerin örtülerinin kaldırılarak gümüş içerikli kremlerle tedavisinin daha erken epitelizasyon sağlayabileceği gösterilmiştir. ${ }^{[7]}$ Yine aynı çalışmada, iyileşmiş büllerin üzerinden kesi yapılmasının, enfeksiyon başta olmak üzere yara iyileşme sorunlarını arttıracağı tekrar belirtilmiştir. Daha ileri yumuşak doku yaralanmalarında, kırığın kalıcı tedavisi için muhtemel yumuşak doku debridmanlarının ve plastik ve rekonstrüktif cerrahi tekniklerinin de sıklıkla gerekebileceği ön görülebilir. Bu durumda, kalıcı redüksiyon ve tespit, iyi bir debridman sonrası yapılacak flep cerrahisi ile birlikte planlanmalıdır. Tscherne 2 ve üzeri yumuşak doku hasarlarında, kompartman sendromunun gelişebileceği akılda bulundurulmalıdır. Bu durumda; klinik bulgular yakın izlenmeli, eğer klinik bulgular güvenilir değil ise kompartman içi basınçlar gerektiğinde tekrarlayan şekilde ölçülerek, kalıcı hasar oluşmadan kompartman sendromu tedavisi yapılmalıdır.

En özet haliyle, yumuşak dokuların açık cerrahiye hazır hale geldiğinin en önemli işareti, ayak bileğinin ön ve arka kısmında kırışma testinin pozitif olmasıdır.

\section{KESI VE CERRAHI YAKLAŞIMIN PLANLAMASI, KIRIĞIN ANLAŞILMASI}

Açık redüksiyon ve kalıcı tespit için, kırığın çok iyi tanımlanmış olması gerekir. Yumuşak dokuların ve nörovasküler durumun ortaya konmasının ardından, kemik etkileniminin değerlendirilmesi için düz filmler incelenir. Ön-arka ve yan ayak bileği grafilerinin kırığın tüm uzanımlarını göstermemesi ihtimali olduğundan, grafilerin tibianın tümünü görecek şekilde elde edilmesi önerilir. Metafizyel parçalanma fazla olduğunda, bu grafilerden yeteri bilgi alınamayabilir. Bu nedenle, basit redüksiyon ve/veya bazen traksiyon ile birlikte grafiler elde edilmesi, kırı̆ğ ilk geliş anındaki tanımlanmasına yardımcı olur. Ancak, bilgisayarlı tomografi (BT) kesitleri, pilon kırıklarının tedavi öncesi değerlendirme aşamasında vazgeçilmezdir. Aksiyel kesitlerin yanında koronal ve sagittal kesitler dikkatle incelenerek tanımlamalar yapılmalı ve tedavi planına geçilmelidir. Özellikle BT kesitlerinin incelenmesi sonrası, kemikte en fazla etkilenen bölgelerin Şekil 1'de önerilen biçimde haritalanması, girişim planlamasında kolaylık sağlayacaktır. Başarılı klinik sonuçlar için, fazla parçalanan bölgenin direkt redüksiyonu ve metafizyel kemiğin yapısal olarak doldurulup plak ile desteklenmesi gereklidir. Bu nedenle, yumuşak dokular izi veriyor ise, metafizyel kemik ve eklem yüzünün daha fazla hasarlandığı bölgeye rahat ulaşılmasına izin veren bir cerrahi yaklaşım tercih edilmelidir. Şekil 2'deki olgunun grafileri incelendiğinde, ileri derecede kısalma olduğu, fibuladaki üst üste binmeden rahatlıkla anlaşılmaktadır. Ayrıca, fibulada valgus yer değiştirmesi bulunması, daha fazla etkilenmenin lateral kolonda olduğunu düşündürmektedir. Düz filmler eklem yüzündeki etkilenmeyi çok net göstermemekte, sadece 


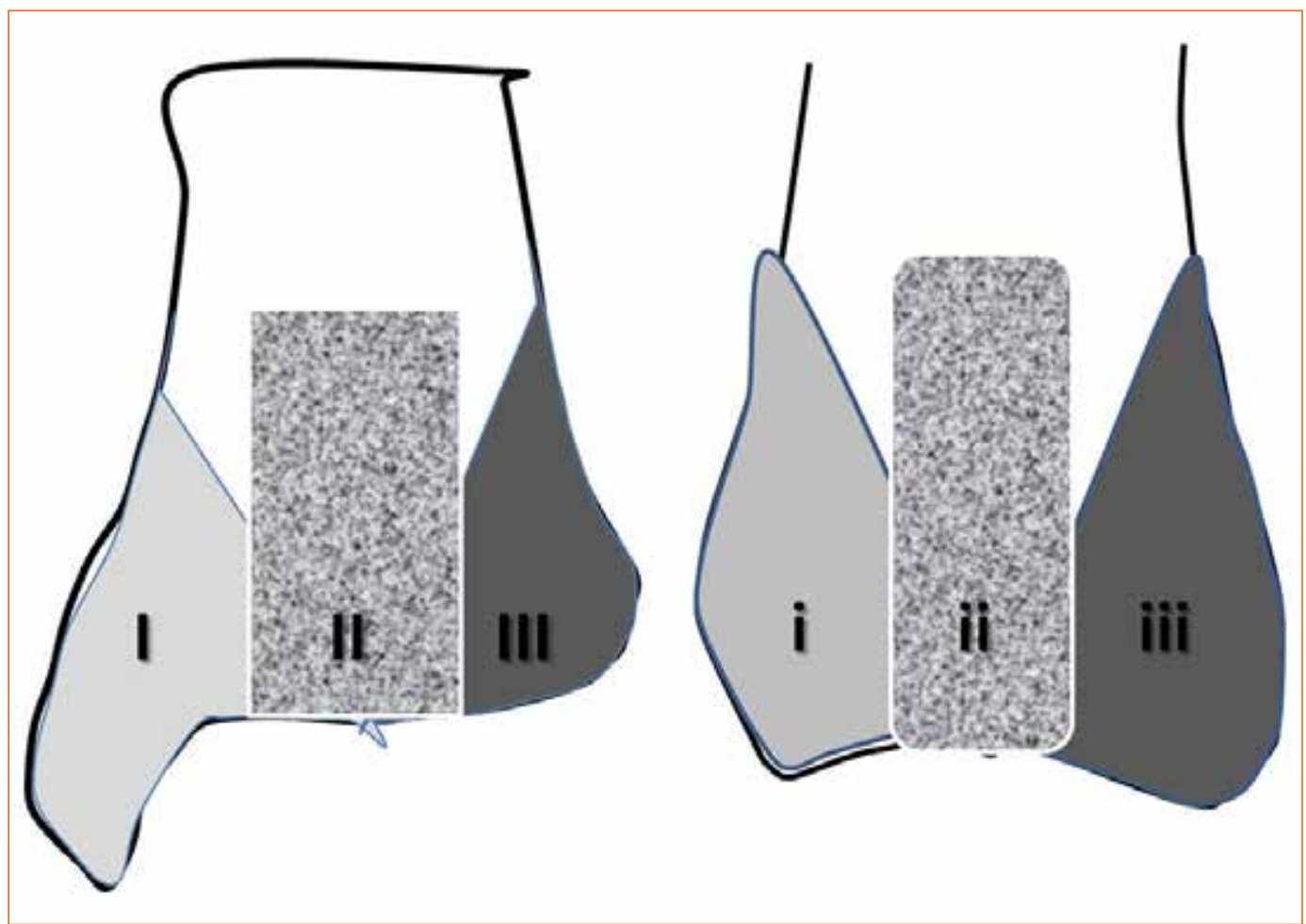

Şekil 1. a, b. Pilon kırıklarında sık etkilenen kemik bölgelerin kolonlar halinde gösterilmesi. Koronal plandaki, mediyal (I), santral (II) ve lateral (III) kolonlar (a); sagittal plandaki, ön (i), orta (ii) ve arka (iii) kolonlar.
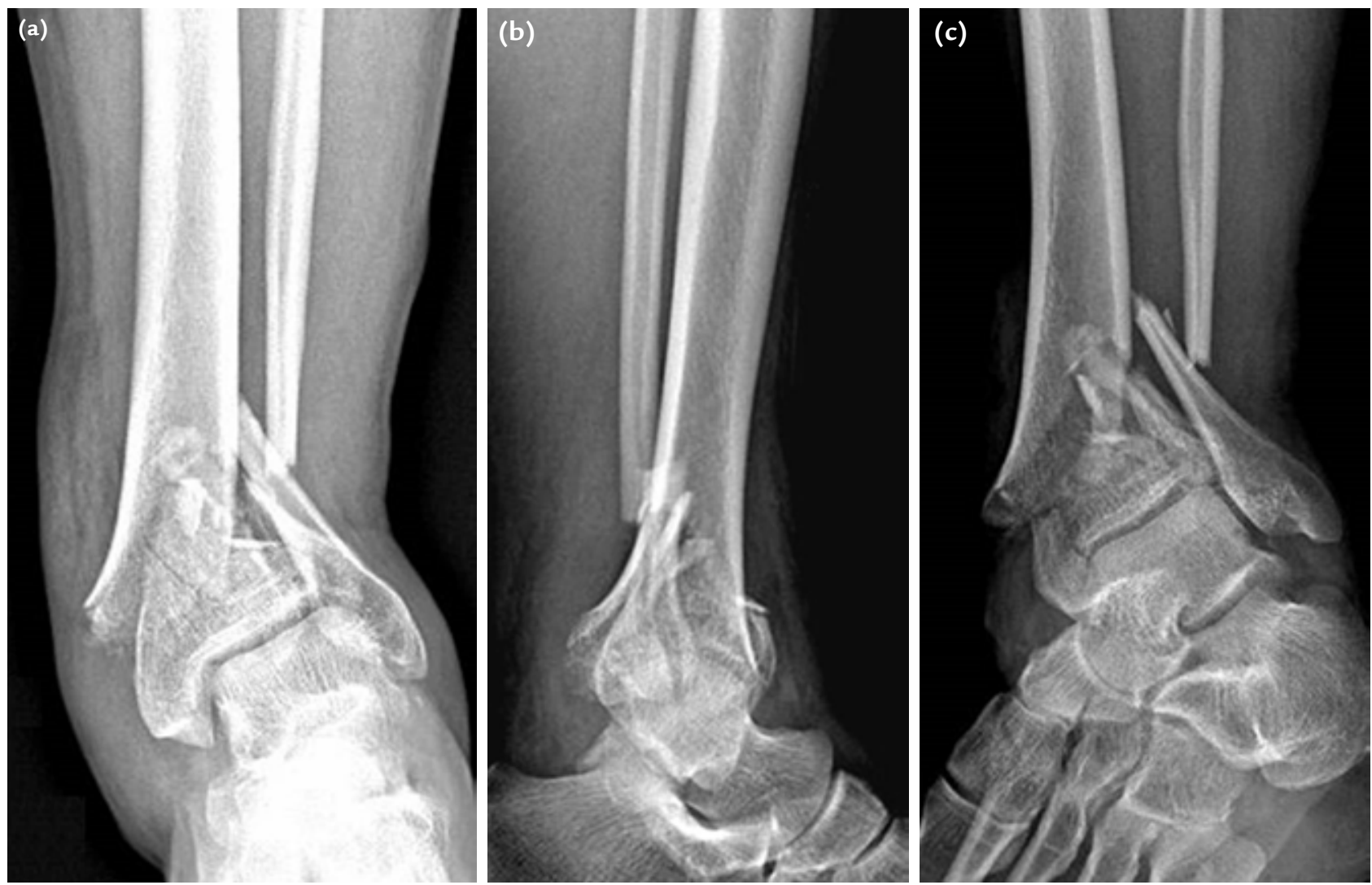

Şekil 2. a-c. Yüksekten düşen genç erişkin hastanın ön-arka (a), yan (b) ve iç rotasyonda (c) oblik düz grafileri. 

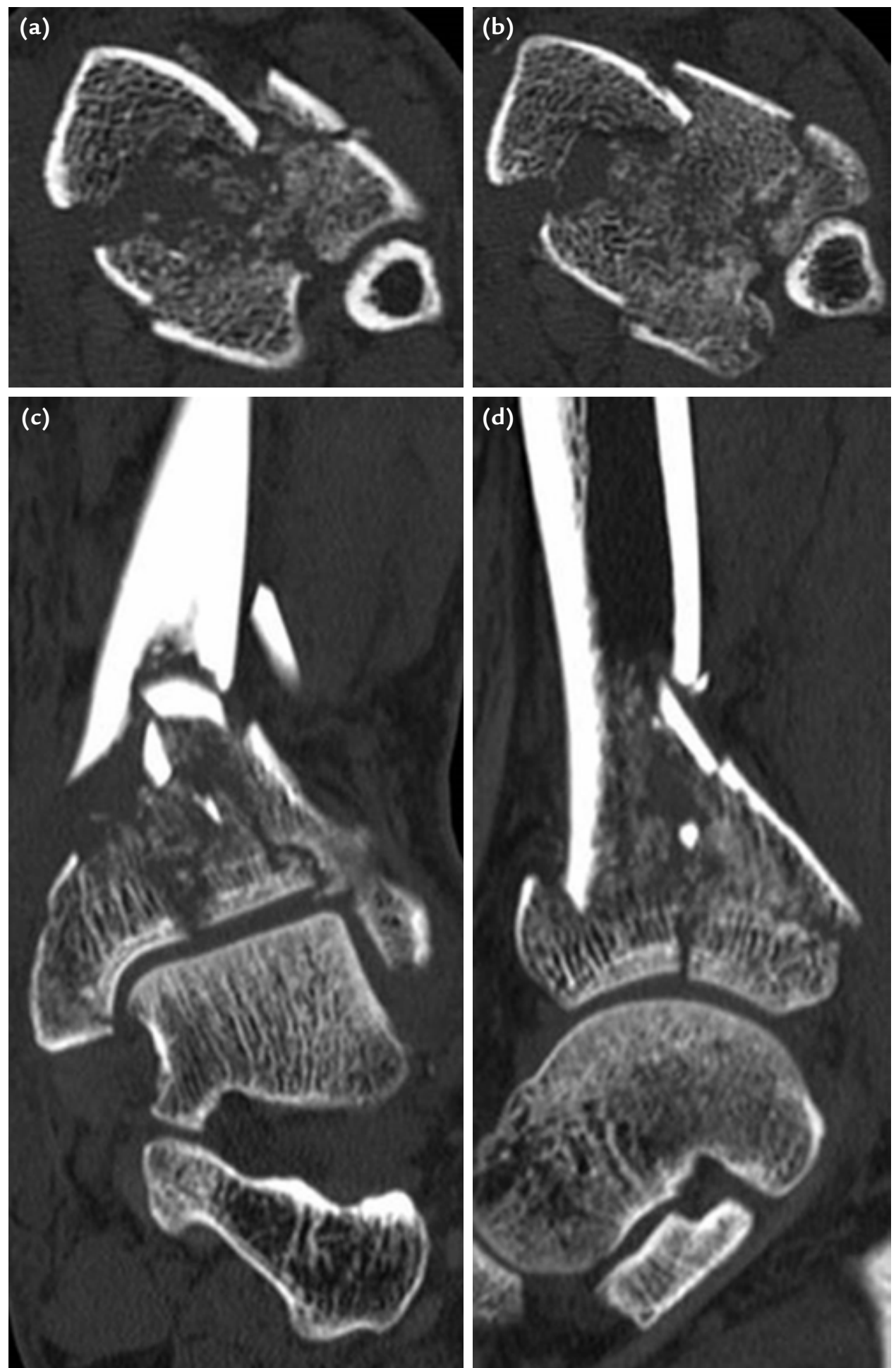

Şekil 3. a-d. Şekil 2'deki hastanın transvers (a ve b), koronal (c) ve sagittal (d) bilgisayarlı tomografi kesitleri.

iç rotasyondaki oblik grafide ekleme inen kırık çizgileri fark edilmektedir. Ancak, eklemdeki yer değiştirme düz filmlerde net olarak değerlendirilememektedir. Aynı olgunun BT kesitleri, eklem yüzü etkilenimini daha net göstererek tedavi planını yönlendirmektedir (Şekil 3). $\mathrm{Bu}$ olguda, anterolateral ve posterolateral parçalanma 
Tablo 1. Pilon kırıklarında daha fazla etkilenen kemik anatomik bölgesine göre sık kullanılan direkt cerrahi yaklaşım önerileri

\begin{tabular}{cl}
\hline $\begin{array}{c}\text { Parçalanma bölgesi } \\
\text { (Şekil 1. a ve b) }\end{array}$ & Direkt cerrahi yaklaşım önerisi \\
\hline I & Anteromediyal \\
II & Anterior \\
III & Anterolateral \\
i & Anterior yaklaşım (...lardan biri) \\
ii & Anterior \\
iii & Posterior yaklaşım (...lardan biri)
\end{tabular}

daha fazladır. Bu bölgelerin redüksiyonu ve yapısal olarak desteklenmesi için açık cerrahide posterolateral ve anterolateral direkt yaklaşımlar uygun seçenekler olacaktır. Mediyaldeki az yer değiştirmeli kırık için perkütan yöntemler kullanılabilir. Kural olmamakla birlikte, Şekil 1'de tarif edilen daha fazla hasar görmüş anatomik bölgelere göre önerilebilecek direkt cerrahi yaklaşımlar Tablo 1'de özetlenmiştir. Fazla parçalanan bölgelerin birden fazla olması ve açık cerrahi ile bu bölgelere tedavi planlanması halinde, birden fazla cerrahi yaklaşım kullanılması veya genişletilmiş yaklaşımlardan yararlanılması mümkündür. Bu cerrahi yaklaşımlar sonraki bölümde özetlenecektir. Tekrar vurgulamak gerekirse, Tablo 1'de önerilen cerrahi yaklaşımlar, genel olarak kırıkların büyük bölümünde cerrahiyi kolaylaştırır; ancak yumuşak dokuların durumuna ve eldeki imkanlara göre değişik tedavi seçenekleri planlanabilir. Mehta ve ark., posterior eklem ve anteromediyal parçalanmalı birçok AO/OTA Tip $B$ ve $C$ pilon kırıklarının anterolateral yaklaşımla düzeltilip tespit edilebileceğini bildirdikleri yayınlarında, ameliyat sırasında baş lambaları, distraksiyon cihazları ve redüksiyon için klempler kullanılmasının başarılı redüksiyona yardımcı olduğundan bahsetmişlerdir. ${ }^{[8]}$ Posterior eklem yüzünün de redüksiyonu gereken ve anterior tibial korteksin kırık olduğu pilon kırıklarında; anterior cerrahi yaklaşımlardan biri tercih edilerek, tibia ön korteksi kaldırıldıktan sonra, eklem redüksiyonu arkadan başlanıp öne doğru gelinerek tamamlanabilir. Redüksiyon için direkt yaklaşımların tercih edilmediği olgularda, ameliyat içi görüntüleme daha da önemli hale gelir.

\section{PILON KIRIKLARINDA KULLANILAN CERRAHI YAKLAŞIMLAR}

Pilon kırıklarının tedavisinde kullanılacak her türlü cerrahi yaklaşım için geçerli en temel kural, tam kat flepler dışındaki disseksiyonların yara iyileşme sorunlarını arttıracağıdır. Bu nedenle cerrahi yaklaşım, cilde dik kesilerle başlayan ve katmanlar arasında fazla disseksiyonu içermeyen şekilde yapılmalıdır. Sık kullanılan bazı cerrahi yaklaşımlar ve bunların basit teknik özellikleri aşağıda tanımlanmıştır.

\section{Anterolateral Yaklaşım}

Sıklıkla anterior kolonda parçalanması fazla olan, valgus yer değiştirmeli ve çökmeli pilon kırıklarında ve özellikle Chaput kırık parçasının redüksiyonunun ve ayrı tespitinin gerektiği durumlarda tercih edilir. Kesinin işaret noktaları, 4. metatars çizgisi, eklem çizgisi ile tibia krestinin lateralidir. Eklem çizgisinin $4 \mathrm{~cm}$ proksimalinden başlayan düz kesi, eklemin 4-5 cm distaline kadar yaklaşık $10 \mathrm{~cm}$ uzunluğunda uzatılır. Çok derinleşmemeye özen gösterilerek, tam kat kesi yapıldıktan sonra, fasyanın üzerinde peroneal sinirin yüzeyel dalı bulunarak korunmalıdır. Fasya ortaya konulduktan sonra, keskin olarak açılır. Fasyanın distale doğru kalınlaşması olan ekstansör retinakulum, kapatma sırasında dikkatlice onarılmalıdır. Bu yapının onarılmaması, tendonlarda yay teli şekil bozukluğuna neden olur. Fasya açıldıktan sonra, anterior kompartman yapılarıyla karşılaşılır. Kasın en lateralinden künt disseksiyon yapılarak, tüm anterior kompartman yapıları bütün olarak mediyale hareketlendirilebilir. Bu bütünün içinde, anterior tibial arter-ven ve derin peroneal sinir de bulunur. Anterior kompartman yapılarının ekartasyonu ile, eklem ve kırık bölgesine ulaşılmış olur. Bu yaklaşımla, anterior ve lateral yapılar doğrudan görülerek girişim yapılabilir. Ancak, mediyal kolona doğrudan ulaşmak mümkün değildir (Şekil 4). Yine, bu yaklaşımın proksimale uzatılarak kullanılması önerilmez. Bunun nedeni, proksimalde anterior kompartman içeriğinin ekartasyonunun güçleşmesi ve hasar ihtimalinin artmasıdır. Bu yaklaşımla, fibula redüksiyonu ve tespiti de yapılabilir.

\section{Genişletilmiş Anterior Yaklaşım}

Tüm kolonların belirgin derecede etkilendiği, parçalanmanın fazla olduğu pilon kırıklarında tercih edilir. Anteriorda lateral ve mediyal kolonlar doğrudan görülerek, gerekli girişimleri yapılabilir. Posterior etkilenme de var ise, ön parçalar pencere şeklinde açılarak posterior redüksiyon yapılabilir. Kesi, mediyal malleolün 1-2 $\mathrm{cm}$ distalinden başlar ve eklem çizgisi seviyesinde orta hattın lateraline geçecek şekilde, transverse yakın oblik şekilde proksimale ilerler. Kesi, eklem çizgisi seviyesinde $110^{\circ}$ açı yapacak şekilde, proksimale düz ilerleyecek biçimde 10-12 cm daha devam eder. Tam kat cilt flepleri oluşturulur ve ekstansör retinakulum ortaya konur. Retinakulum açılır. Mümkünse, tibialis anterior tendon kılıfı açılmadan tendon hareketlendirilir. Cilt flebi 


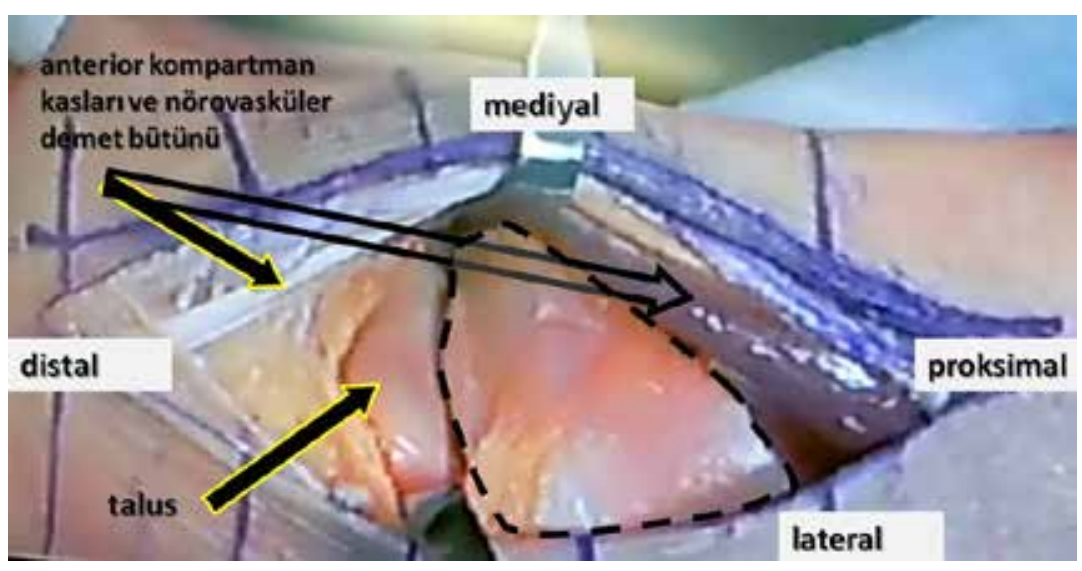

Şekil 4. Anterolateral yaklaşılımın kadavra disseksiyonu görüntüsü. Kesikli çizgilerle çevrili alan, tibia distali anteriorunda doğrudan görülen bölgeyi işaret etmektedir.

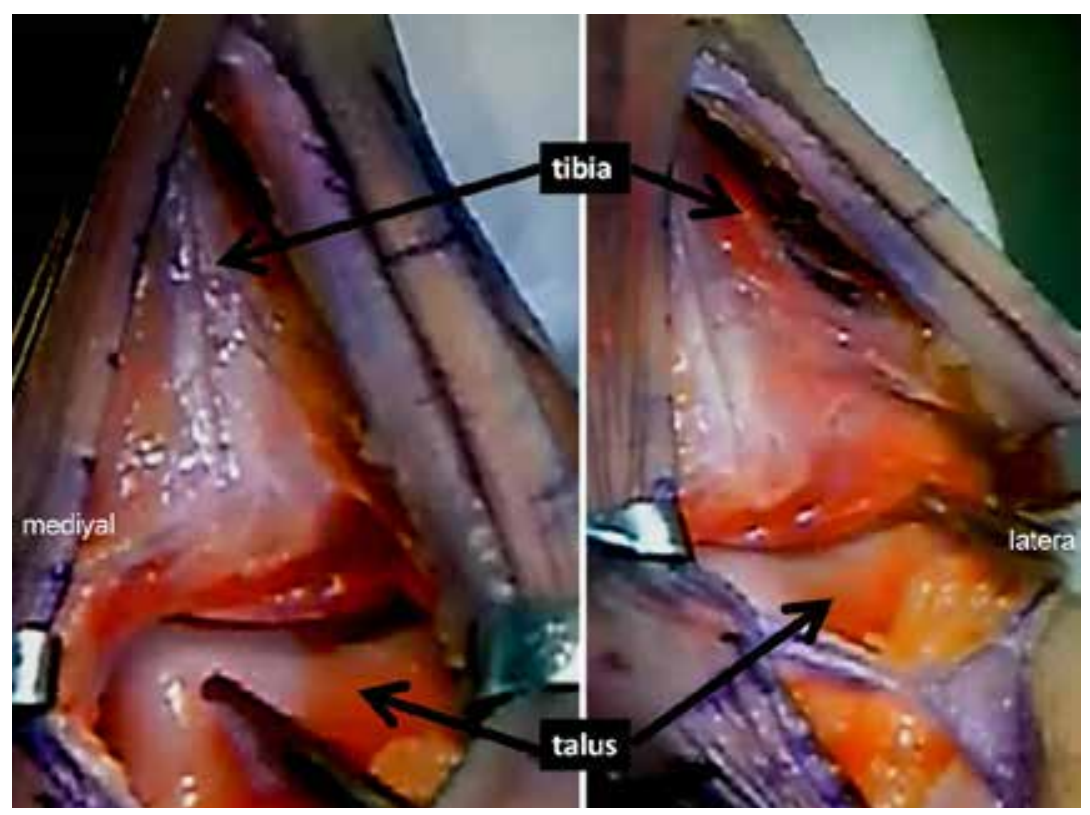

Şekil 6. Anteromediyal yaklaşımın kadavra disseksiyon görüntüsü. Yumuşak dokunun mediyale ekartasyonu ile görülebilen alan (a); laterale ekartasyon ile anterolateralde Chaput parçasına kadar görüş mümkündür (b). Ancak, bu yaklaşımda Chaput parçasına ayrıca tespit uygulamak genellikle mümkün değildir. Tespit için perkütan veya ayrı küçük anterolateral kesi yapılabilir.

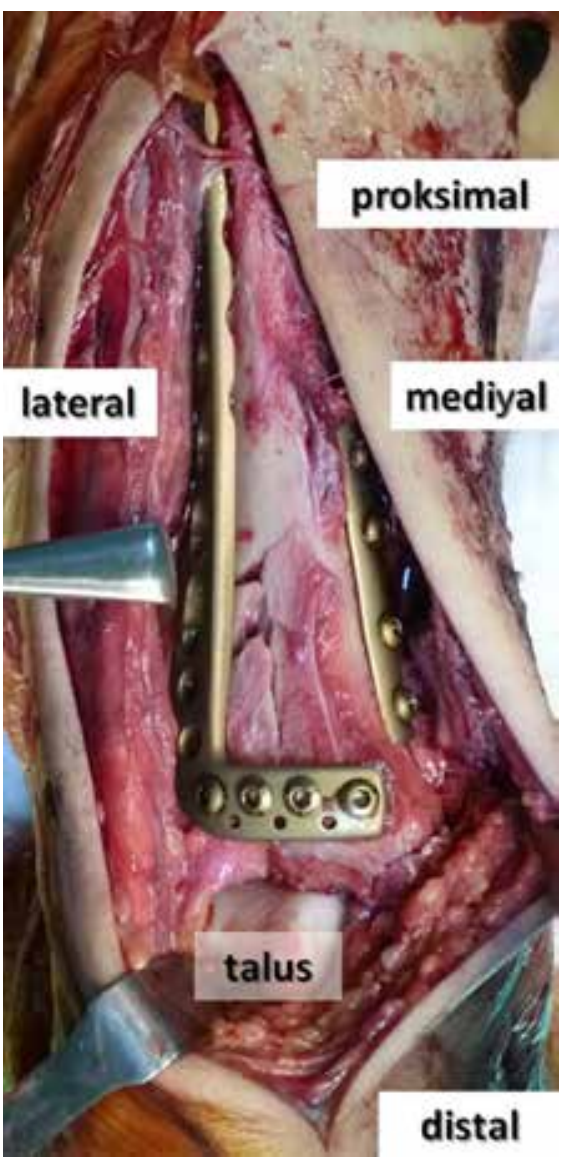

Şekil 5. Genişletilmiş anterior yaklaşım: Sadece üç basit ekartörün fazla gergin olmadan çekmesiyle, distal tibia metafiz, eklem ve cisminin geniş görüntülenmesi elde edilebilir. Şekilde, cerrahi redüksiyon ve tespiti tamamlanmış bir pilon kırığında bu açılımla uygulanmış anterolateral ve mediyal plak-vidalar görülmektedir. mediyale, tibialis anterior tendonu laterale ekarte edilir. Eklem kapsülü uzunlamasına açılarak, talus ortaya konur. Disseksiyon, subperiosteal olarak lateralde Chaput parçası ve tüm kırık doğrudan görüntüleninceye kadar devam eder. Aynı keşide, distal tibia metafiz ve cismi görülebilir ve doğrudan girişimler yapılabilir (Şekil 5).

\section{Anteromediyal Yaklaşım}

Mediyal ve orta/santral kolonun daha fazla etkilendiği pilon kırıklarının seçkin yaklaşımı olarak kullanılır. Lateralde Chaput kırık parçası görülebilir ve redükte edilebilir, ancak parçaya doğrudan implant uygulanabilmesi bu yaklaşımla kolay değildir ve genellikle ayrı kesi gerektirir (Şekil 6). Anteromediyal yaklaşım kesisi, eklem çizgisinin $8 \mathrm{~cm}$ kadar proksimalinde tibianın hemen lateralinden başlayarak distale düz iner; eklem çizgisini de düz geçerek, naviküla bazisinde sonlanır. Tam kat cilt flebi oluşturulur. Tibialis anterior tendonu ve kılıfının mediyalinden faysal kesi yapılır. Eklem uzunlamasına düz açılır ve subperiosteal disseksiyonla devam edilir. Geniş bir açılım elde edilerek, doğrudan kırık girişimleri yapılabilir. 


\section{Posteromediyal Yaklaşım}

Posterior yaklaşımlar sık kullanılmaz. Ancak, posterior parçalanmanın da fazla olduğu ve destek plak gerektiren kırıklarla, posterior redüksiyon ve tespitin ön kolonlardaki redüksiyon ve tespiti kolaylaştıracağı düşünülen olgularda endikedir. Posteromediyal yaklaşım için, hasta pozisyonu supin veya prone olabilir. Supin pozisyon seçilecekse, bacağın dış rotasyonunu kolaylaştıracak biçimde, karşı kalçanın altına yükseklik konabilir. Kesi, Aşil tendonu ile tibia posterior sınırının genellikle ortasında yer alır ve proksimalde tibiaya paralel, distale gelindikçe tibialis posterior tendonuna paralel ilerler. Eğer sadece redüksiyon planlanıyorsa, tibiaya yakın; implant yerleştirilmesi planlanıyorsa, Aşil tendonuna yakın kesi tercih edilebilir. Cilt altı geçildikten sonra krural fasya proksimalden dikkatlice açılır ve nörovasküler demet bulunarak korunur. Derin disseksiyon planı, kırık parçaların yerine ve yapılacak işleme göre değiştirilebilir. Girişim planlanan ana kırık bölgesi eklemin proksimalindeyse, hemen tibia ile tibialis posterior tendonu arasından girilebilir. Diğer bir derin disseksiyon planı, tibialis posterior tendonu ile fleksör dijitorum komünis tendonu arasından olabilir. Üçüncü derin disseksiyon planı, fleksör hallusis longus ile fleksör dijitorum longus arasıdır. Bu son planda, nörovasküler demetin disseksiyonu ve ekartasyonu gerekir. Demet anteromediyale veya posterolaterale ekarte edilebilir. Posteromediyal yaklaşım, geniş görüntü sağlamadığı ve lateral kırık parçalarına ulaşımın rahat olmaması nedeniyle sık kullanılmaz.

\section{Posterolateral Yaklaşım}

Bu yaklaşım için kesi, Aşil tendonu ile fibulanın posterior sınırlarının ortasında yer alır. Kesi boyu yapılacak girişime göre değişebilir. Cilt altında sural sinire dikkat edilmelidir. Derin fasya açıldıktan sonra, fleksör hallusis longus ve peroneal tendonlar arasında künt disseksiyon yapılarak giriş planı oluşturulur. Fleksör hallusisin fibulaya yapışan proksimal lifleri, keskin bir şekilde fibuladan kaldırılarak tibia distali posterioruna ulaşılmış olur. Aynı yaklaşımla, fibula redüksiyonu ve tespiti de yapılabilir.

\section{AÇIK REDÜKSIYON VE TESPIT IÇIN TEKNIK IPUÇLARI}

Yumuşak dokulara mümkün olan en az hasar verecek şekilde girişim uygulanması, pilon kırıklarının açık cerrahi tedavisindeki en önemli kural ve başarı için ipucudur. Geniş fleplerden mümkün olduğunca kaçınılmalı, yumuşak doku izin veriyorsa kırık bölgesine doğrudan ulaşılacak yaklaşım tercih edilmelidir. Kompleks kırıklarda tek genişletilmiş yaklaşımla girişim planlandığında, düzeltme için sivri uçlu klemplerin değişik boyları hazır bulundurulmalıdır (Weber, Mayo, asimetrik asetabulum redüksiyon klempleri). Yine, kompleks kırıklarda iki kesi (posterolateral+anteromediyal veya posteromediyal+anterolateral gibi) kullanıldığında, arka ve ön kırık parçalarını birlikte tutmak için kullanılan redüksiyon klepinin, arada kalan yumuşak doku köprüsünü bası altında bırakmamasına özen gösterilmelidir. Bunun için, asetabulum kırık cerrahisinde kullanılan daha geniş tutma çaplı klempler kullanılabileceği gibi, daha büyük parçanın olduğu tarafa klemp için bir post vidası uygulanarak, klempin köprü yumuşak dokudan uzaklaşması sağlanabilir. Kompleks kırıkların tek kesi ile tedavisinde ameliyat için, görüntülemenin sorunsuz ve ideal pozisyonlarda yapılabileceği hasta pozisyonu sağlanmalı ve radyolüsen alanı geniş ameliyat masası kullanılmalıdır.

Kullanılacak implantlar, özellikle anterior kompartmanda fazla yer kaplamayacak şekilde seçilmelidir. Mümkün olduğunca, vidaların başları belirgin bırakılmamalı, bunun tendon irritasyonu yapabileceği akılda bulundurulmalıdır.

Cerrahi tedavinin önemli aşamalarından biri de kapatmadır. Anterior girişimlerde ekstansör retinakulumun onarılması, iyileşme sonrası anterior kompartman tendonlarının yay teli (bowstring) deformitesini önlemek için şarttır. Cilt altı dokusunun kalın olduğu olgularda, yaklaştırma cilt altı dikişleri kullanılmalıdır. Cilt için en uygun teknik Allgöwer-Donati ve dikiş materyali de emilmeyen monofilaman dikişlerdir. Allgöwer-Donati dikiş tekniğinin, kutanöz kan dolaşımını değişik gerginlik derecelerinde çok az bozduğu ve hasarlı dokularda güvenli kullanımının mümkün olduğu gösterilmiştir. ${ }^{[9]}$

Sonuç olarak; pilon kırıklarında yaralanmanın anlaşılması, tedavi planının en önemli aşamalarından biridir. Yumuşak dokuların uygulanacak tedaviye hazır olup olmadığı değerlendirilmeli, kemik doku yaralanması düz grafiler ve bilgisayarlı tomografi kesitleri ile dikkatli bir şekilde incelenerek planlama yapılmalıdır. Parçalanması olmayan, anatomik düzeltmenin mümkün olduğu durumlarda, fibula kırığının redüksiyon ve tespiti pilon redüksiyonu için avantaj sağlar. Aynı seansta olsun, farklı seanslarda olsun, fibula redüksiyon ve tespit kesisinin pilon için yapılacak kesiye çok yakın olmaması için, fibula tespitinden önce pilon kesin tedavisi için planın belli olması gerekir. Pilonda daha fazla etkilenen ve yer değiştirme olan bölge veya bölgelerin desteklenmesi, temel kurallardan biridir. Tercih edilecek yaklaşımın kırığa büyük flepler oluşturmadan yaklaşılmasına izin vermesine özen gösterilmelidir. ileri derecede parçalanmalı ve birden fazla kesi ihtimalinin olduğu kırık tedavilerinde 
genişletilmiş yaklaşımların kullanılmasının gerekebileceği akılda bulundurulmalıdır. Tüm kesilerde, tam kat ve ekartasyonla çok fazla ezilmeyecek flepler oluşturulmalıdır. Özellikle, mediyal ve anteromediyalde çıkıntı oluşturacak implantlardan kaçınılmalıdır. Ekstansör retinakulum, tendonlarda yay teli deformitesi oluşmasını engellemek için onarılmalıdır. Cilt dolaşımını bozmayacak şekilde dikişler kullanılması da klinik sonuçlar üzerinde etkili olur.

\section{KAYNAKLAR}

1. Crist, BD, Khazzam M, Murtha YM, Della Rocca GJ. Pilon fractures: advances in surgical management. J Am Acad Orthop Surg 2011;19(10):612-22.

2. Early JS, Tenenbaum S. Soft Tissue Management of Closed Tibial Pilon Fractures. Tech Orthop 2014;29(1):2-7. Crossref

3. ErtlW, Henley MB. Provisional External Fixation for Periarticular Fractures of the Tibia. Tech Orthop 2002;17(2):135-44.
4. Antoci V, Voor MJ, Selidson D, Roberts CS. Biomechanics of external fixation of distal tibial extra-articular fractures: is spanning the ankle with a foot plate desirable? J Orthop Trauma 2004;18(10):665-73.

5. Shah CM, Babb PE, McAndrew CM, Brimmo O, Badarudeen S, Tornetta P 3rd, Ricci WM, Gardner MJ. Definitive plates overlapping provisional external fixator pin sites: is the infection risk increased? J Orthop Trauma 2014;28(9):518-22. Crossref

6. Tscherne $\mathrm{H}$. Principles of primary treatment of fractures with soft tissue injury. Orthopade 1983;12(1):9-22.

7. Strauss EJ, Petrucelli G, Bong M, Koval KJ, Egol KA. Blisters associated with lower-extremity fracture: results of a prospective treatment protocol. J Orthop Trauma 2006;20(9):618-22.

8. Mehta S, Gardner MJ, Barei DP, Benirschke SK, Nork SE. Reduction strategies through the anterolateral exposure for fixation of type B and C pilon fractures. J Orthop Trauma 2011;25(2):116-22. Crossref

9. Sagi HC, Papp S, Dipasquale T. The effect of suture pattern and tension on cutaneous blood flow as assessed by laser Doppler flowmetry in a pig model. J Orthop Trauma 2008;22(3):171-5. Crossref 